\title{
Perbandingan Metode Audio Dan Audio Visual Terhadap Pengetahuan Tentang Pemeriksaan Payudara Sendiri (SADARI) Pada Remaja Putri
}

\author{
Izza Swestivioka ${ }^{1}$, Iroma Maulida ${ }^{2}$, Nora Rahmanindar ${ }^{3}$ \\ ${ }^{1,2,3}$ DIII Kebidanan Politeknik Harapan Bersama, Tegal, 52147, Indonesia
}

\begin{tabular}{l}
\hline ARTICLE INFORMATION \\
\hline Article Trace \\
Submission: June, 10, 2019 \\
Final Revision: September 01, 2019 \\
Available online: October 26, 2019 \\
\hline
\end{tabular}

Kata kunci :

Jenis media, SADARI, remaja Putri

Key Word :

Type of media, SADARI, girl

Contact:

izzaswestuvioka@gmail.com

\begin{abstract}
A B S T R A K
Pemeriksaan payudara sendiri (SADARI) merupakan suatu teknik penyaringan yang sederhana dan baik untuk mendeteksi dini gejala gangguan pada payudara. Intervensi berupa penyuluhan sangat dibutuhkan untuk meningkatkan pengetahuan mengenai SADARI. Tujuan penelitian ini untuk mengetahui pengaruh jenis media komunikasi dengan pengetahuan SADARI pada remaja putri di sala satu SMA di TEGAL. Penelitian ini adalah penelitian quasi eksperimen. Populasi penelitian ini adalah remaja putri kelas X yang berjumlah 60 orang. Metode pengambilan sampel diambil secara random. Responden dibagi menjadi dua kelompok yaitu kelompok siswi yang mendapatkan metode penyuluhan dengan media audio visual (video) dan kelompo yang akan diberikan penyuluhan dengan media audio (ceramah). Analisis uji statistic menggunakan uji $t$. Hasil penelitian ini menunjukan bahwa kedua jenis metode penyuluhan mempengaruhi pengetahuan SADARI dengan Independent Sample T-test diperoleh nilai signifikansi $0,000$ ( $P$ value $<0,05)$ dengan perolehan rata - rata pengetahuan pada kelompok yang mengguakan video adalah 85,70 sedangkan kelompok yang menggunakan media audio memiliki rata-rata pengetahuan dengan skor 73,83 . Penelitian ini menunjukkan pelaksanaan penyuluhan tentang SADARI pada remaja putri dapat meningkatkan pengetahuan pada remaja putri tentang tanda dan gejala gangguan pada payudara.
\end{abstract}

\begin{abstract}
A B S T R A C T
Breast self-examination is a simple and good filtration technique for early detection of symptoms of breast disorders. Counseling is a necessary intervention to improve knowledge about SADARI. The purpose of this research is to know the influence of media types of communication with the knowledge in the young women in a high school in TEGAL. This was a Quasi Experimental Study. The population of this research is 60 young girls. The sampling method is taken randomly. Respondents were divided into two groups: the group of students who got information through audio visual media (video) and the group who got information through audio. Statistical analysys using $\mathrm{T}$ test. The results of this study showed that both types of extension methods affect the knowledge with Independent Sample T-Test obtained significance value 0.000 ( $\mathrm{P}$ value $<0.05$ ). The average knowledge in the group is 85.70 while the group that uses audio media has an average knowledge with a score of 73.83. This research demonstrates the implementation of awareness about Breast self examination on young girls can increase knowledge in about signs and symptoms of disorders in the breast.
\end{abstract}




\section{PENDAHULUAN}

Periksa payudara sendiri (SADARI) merupakan suatu teknik penyaringan yang sederhana dan baik untuk penyakit payudara. Meskipun SADARI tidak mahal, tidak nyeri, tidak berbahaya dan nyaman, namun hanya sekitar dua pertiga wanita mempraktikkannya sekurang kurangnya sekali setahun dan hanya sepertiga mempraktekkannya tiap - tiap bulan seperti dianjurkan. Wanita yang melakukan teknik itu, hanya sekitar setengahnya yang melakukan dengan benar. Hal ini disebabkan karena minimnya informasi dan kurangnya pengetahuan tentang SADARI (Wardhani, Saraswati, \& Adi, 2017)

Berdasarkan Patological Based Registration atau berdasarkan pencatatan pemeriksaan jaringan, kanker payudara mempunyai angka kejadian relatif $11,5 \%$, diperkirakan di Indonesia mempunyai angka kejadian minimal 20 ribu kasus baru pertahun, dengan kenyataan 50\% kasus baru ditemukan pada keadaan stadium lanjut (nasihah \& Rodliyatun, 2013): Menurut data GLOBOCAN, International Agency for Research on Cancer (IARC) tahun 2012 diketahui bahwa kanker payudara merupakan penyakit kanker dengan persentase kasus baru (setelah dikontrol oleh umur) tertinggi, yaitu sebesar 43,3\%, dan persentase kematian (setelah dikontrol oleh umur) akibat kanker payudara sebesar 12,9\%. Penyakit kanker payudara merupakan penyakit kanker dengan prevalensi tertinggi kedua setelah kanker serviks di Jawa Tengah pada tahun 2013, yaitu kanker serviks sebesar 1,2\% atau setara dengan 19,734 jiwa dan kanker payudara sebesar $0,7 \%$ atau setara dengan 11.511 jiwa, sedangkan prevalensi kanker payudara tertinggi terdapat pada Provinsi D.I. Yogyakarta, yaitu sebesar 2,4\%. Berdasarkan estimasi jumlah penderita kanker payudara terbanyak terdapat pada Provinsi Jawa Tengah yaitu sebesar 11.511 jiwa (Profil Provinsi Jawa tengah, 2016 dalam Depkes, 2018).

Untuk deteksi dini kanker payudara dilakukan pemeriksaan Clinical Breast Examination (CBE) yaitu pemeriksaan payudara yang dilakukan oleh tenaga terlatih. Pemeriksaan ini dipakai untuk mendeteksi kelainan - kelainan yang ada pada payudara dan untuk mengevaluasi kanker payudara pada tahap dini sebelum berkembang menjadi tahap yang lebih lanjut. Dari keseluruhan perempuan yang dilakukan pemeriksaan $\mathrm{CBE}$ terdapat $1,42 \%$ perempuan terdapat benjolan. Sedangkan Kabupaten Tegal terdapat perempuan yang memiliki benjolan di payudara dengan presentase $0,92 \%$. Tingginya persentase benjolan menunjukkan faktor risiko kanker payudara di wilayah tersebut (Profil Provinsi Jawa tengah, 2016 dalam Depkes, 2018). Di Kecamatan Jatinegara didapatkan perempuan memiliki benjolan di payudara berdasarkan SADANIS dengan presentase $0,79 \%$ dan presentase kematian karena kanker payudara sebanyak $\quad 0,83 \% \quad$ (Puskesmas Jatinegara, 2018)

Rendahnya pengetahuan atau informasi tentang penyakit kanker serta usaha pencegahan deteksi dini menyebabkan banyak wanita yang belum tertarik atau kurang berminat untuk melakukan usaha deteksi ini. Intervensi berupa penyuluhan sangat dibutuhkan untuk meningkatkan pengetahuan mengenai SADARI. Perilaku yang didasari oleh pengetahuan, kesadaran dan sikap positif, maka perilaku tersebut akan bersifat menetap, sebaliknya apabila perilaku tidak didasari oleh pengetahuan dan kesadaran maka tidak akan berlangsung lama. Penyuluhan kesehatan merupakan salah satu bentuk kegiatan pendidikan kesehatan. Penyuluhan kesehatan dalam promosi kesehatan diperlukan sebagai upaya meningkatkan pengetahuan dan sikap seseorang tentang kesehatan (Suraya \& Suyanto, 2015)

Pengetahuan untuk pemeriksaan SADARI pada remaja putri dapat dilakukan penyuluhan dengan media audio (ceramah) maupun menggunakan media audio visual (video). Memberikan penyuluhan dengan menggunakan media audio (ceramah) sudah efektif, tetapi menggunakan metode ceramah hanya efektif jika disampaikan selama 15 menit pertama, menit - menit berikutnya daya serap siswa terhadap ceramah mulai menurun (Gulo, W, 2002). Metode ceramah membuat peserta didik menjadi pasif dan bagi peserta didik yang tipe belajar visual akan lebih sulit menerima penjelasan dibandingkan dengan peserta didik yang memiliki tipe belajar audio (Roymond \& Simamora, 2009) 
Menurut piramida Edgar Dale penggunaan video bahwa belajar $50 \%$ adalah apa yang didengar dan dilihat. Video dalam proses pembelajaran sangat cepat dan mudah diingat, dapat diulang bila perlu penjelasan dapat mengembangkan pola kognitif para siswa (Munadi, Y, 2012). Berdasarkan penelitian, organ yang paling banyak dapat menyalurkan pengetahuan adalah mata. Oleh sebab itu, dalam aplikasi pembuatan media, disarankan lebih banyak menggunakan alat - alat visual karena akan mempermudah cara penyampaian dan penerimaan informasi oleh peserta didik (Maryam, 2014). Maka dari itu, jenis media komunikasi dengan media audio dan media audio visual akan mempengaruhi materi yang akan disampaikan.

Studi pendahuluan yang dilakukan pada salah satu sekolah SMA di TEGAL menunjukkan bahwa 15 siswi memiliki pengetahuan yang rendah tentang masalah yang mungkin terjadi pada daerah payudara. Tujuan penelitian ini untuk mengetahui pengaruh metode penyuluhan terhadap pengetahuan remaja putri tentang pemeriksaan payudara sendiri.

\section{METODE PENELITIAN}

Penelitian analitik, dengan rancangan Quasy Experiment. Populasi siswi 60 orang dengan cara total sampling yang dibagi menjadi dua kelompok yaitu kelompok yang menggunakan media audio visual/video) dan kelompok yang menggunakan media audio/ceramah). Untuk menghitung presentase hasil pengetahuan yaitu jumlah jawaban benar dibagi jumlah seluruh item pertanyaan dikali 100. Analisis data menggunakan uji normalitas dan uji hubungan dengan uji $T$ ( $\alpha 5 \%$ / 0,05 dengan CI $95 \%)$.

\section{HASIL DAN PEMBAHASAN}

Tabel 1. Pengaruh jenis media komunikasi dengan pengetahuan SADARI pada remaja putri

\begin{tabular}{cccc}
\hline $\begin{array}{c}\text { Pengetahuan } \\
\text { SADARI }\end{array}$ & $\begin{array}{c}\text { Kelompok } \\
\text { media audio } \\
\text { visual }\end{array}$ & $\begin{array}{c}\text { Kelompok } \\
\text { media Audio }\end{array}$ & $\begin{array}{c}\mathrm{P} \\
\text { Value }\end{array}$ \\
\hline $\begin{array}{c}\text { Nilai Rata-Rata } \\
\text { pasca } \\
\text { penyuluhan }\end{array}$ & 85,70 & 73,83 & 0,000 \\
\hline Selisih & \multicolumn{2}{c}{11,867} & \\
\hline
\end{tabular}

Berdasarkan tabel 1 menunjukkan bahwa bahwa pengetahuan SADARI pada kelompok yang menggunakan media video memiliki nilai rata - rata 85,70, sedangkan pada kelompok yang menggunakan metode ceramah memiliki nilai rata - rata 73,83 dengan $p$ value 0,000 dan hasil uji statistik lebih kecil daripada 0,05 $(0,000<0,05)$ yaitu ada perbedaan. Hal ini sesuai dengan teori piramida Edgar Dale penggunaan video bahwa belajar $50 \%$ adalah apa yang didengar dan dilihat. Video dalam proses pembelajaran sangat cepat dan mudah diingat, dapat diulang bila perlu penjelasan dapat mengembangkan pola kognitif para siswa, sedangkan ceramah hanya $20 \%$ karena mengandalkan indera pendengaran saja (Munadi, Y, 2012)

Menurut penelitian Suhita, Byba Melda (2008), hasil analisis untuk perbedaan pengetahuan tentang SADARI diperoleh nilai $t$ hitung $-5,706$ dengan nilai $\mathrm{p}$ value sebesar 0,000 kurang dari nilai $\alpha$ yang ditetapkan adalah 0,05 , yang berarti ada perbedaan pengetahuan wanita dewasa tentang SADARI dalam upaya deteksi dini $\mathrm{Ca}$ Mammae di Kediri. Nilai selisih rerata skor sebelum dengan setelah penyuluhan menunjukkan nilai negatif yaitu - 1,1919 yang berarti pengetahuan sebelum penyuluhan lebih kecil dari pengetahuan setelah penyuluhan, hal ini berarti health education memberikan pengaruh positif terhadap peningkatan pengetahuan wanita dewasa.

Kelompok intervensi pada penelitian ini merupakan responden yang menggunakan media video dengan harapan meningkatkan pengetahuan SADARI sehingga dapat melakukan SADARI dan dapat mendeteksi sedini mungkin adanya kelainan pada payudara. Dimana pada kelompok intervensi diberikan penyuluhan pengetahuan SADARI menggunakan media video dan kelompok kontrol diberikan penyuluhan pengetahuan SADARI menggunakan metode ceramah, hanya dipantau pengetahuan SADARI pada saat pre test dan post test saja. Hal ini sejalan dengan penelitian (Indriyani, Tiara, 2017) menyebutkan bahwa penyuluhan kesehatan dengan video efektif dalam meningkatkan pengetahuan remaja putri, video sangat berpengaruh terhadap tingkat pengetahuan seorang remaja 


\section{KESIMPULAN}

Berdasarkan perbandingan data post test kelompok intervensi dan kelompok kontrol didapat nilai signifikansi sebesar 0,000 . Hasil uji statistik memberikan nilai signifikansi lebih kecil daripada $0,05 \quad(0,00<0,05)$. Hal ini menunjukan bahwa jenis media komunikasi mempunyai pengaruh pengetahuan SADARI pada remaja putri.

\section{DAFTAR PUSTAKA}

Gulo, W. (2002). Metode Penelitian. Jakarta: Gramedia.

http://www.depkes.go.id/resources/download/pr ofil/PROFIL KES PROVINSI 2016/13 Jateng_2016.pdf di akses pada tanggal 4 Desember 2018.

Munadi, Y. (2012). Media Pembelajaran: Sebuah Pendekatan Baru. Jakarta: Gaung Persada Press.

Nasihah, M., \& Rodliyatun, S. (2013). Gambaran Pengetahuan Remaja Putri Tentang Sadari. Jurnal Midpro, Edisi 1, 1-6. http://journal.unisla.ac.id/ di akses pada tanggal 27 Oktober 2018.

Roymond \& Simamora. (2009). Buku Ajar Pendidikan Dalam Keperawatan. Jakarta: EGC.

Suhita, Byba Melda (2008). Pengaruh Health Education Terhadap Pengetahuan Dan Sikap Wanita Dewasa Tentang " Sadari “ Dalam Upaya Deteksi Dini Ca Mammae
$D i$

Kediri.https://www.neliti.com/id/publicati ons/236478/pengaruh-health-educationterhadap-pengetahuan-dan-sikap-wanitadewasa-tentang-s diakses pada tanggal 4 April 2019.

Suraya, H.N., Romus, I., \& Suyanto. (2015). Pengaruh Penyuluhan Terhadap Pengetahuan Dan Sikap Ibu Pkk Tentang Pemeriksaan Payudara Sendiri (SADARI), Jurnal Online Mahasiswa Fakultas Kedokteran, Vol. 2, No. 2, 1-15. http://jom.unri.ac.id/index.php/JOMFDO $\mathrm{K}$ di akses pada tanggal 2 November 2018.

Wardhani, A.D., Saraswati, L.D., \& Adi, M.S. (2017). Gambaran Pengetahuan Remaja Putri Tentang Sadari Dan Praktik Pemeriksaan Payudara Sendiri. Jurnal Kesehatan Masyarakat, Vol. 5, No. 1, 180-186. http://ejournals1.undip.ac.id/index.php/jkm di akses pada tanggal 27 Oktober 2018.

Data Kesehatan Puskesmas Jatinegara. 2018, Penyakit Tidak Menular. Puskesmas Jatinegara

Indriani, Tiara (2017). Efektifitas Penyuluhan Kesehatan "SADARI" Dengan Media Video Terhadap Pengetahuan Pada Remaja Putri Di SMK YMJ Ciputat. http://repository.uinjkt.ac.id/dspace/bitstre am/123456789/35950/1/Tiara\%2520Indri ani-FKIK.pdf diakses pada tanggal 4 April 2019. 